\title{
Characteristics of Patients with Estrogen Receptor (ER)-Negative, Progesterone Receptor (PR)-Negative, and HER2-Negative Invasive Breast Cancer in Dr. Hasan Sadikin General Hospital, Bandung, Indonesia from 2010 to 2011
}

\author{
Nadytia Kusumadjayanti, ${ }^{1}$ Dharmayanti Francisca Badudu, ${ }^{2}$ Bethy S. Hernowo ${ }^{3}$ \\ ${ }^{1}$ Faculty of Medicine, Universitas Padjadjaran, ${ }^{2}$ Departement of Oncological Surgery, Faculty of \\ Medicine, Universitas Padjadjaran/Dr. Hasan Sadikin General Hospital, Bandung, ${ }^{3}$ Departement \\ of Anatomical Pathology, Faculty of Medicine, Universitas Padjadjaran/Dr. Hasan Sadikin General \\ Hospital, Bandung
}

\begin{abstract}
Background: Breast cancer is the most common type of cancer that has been diagnosed among Indonesian women. One of the subtypes that frequently being studied is the triple negative breast cancer which has poorer prognosis among all subtypes. The objective of this study was to investigate the incidents and the characteristics of triple negative breast cancer patients.

Methods: This study used triple negative breast cancer patients' medical records in Dr. Hasan Sadikin General Hospital. Some characteristics were identified, such as age at presentation, menopause status, tumor size, stage at presentation, grades of tumor, pathological features, and metastatic status. Data were taken during 2010 and 2011 and presented in table.

Results: Thirty women among 252 patients were identified as having triple negative breast cancer. Based on those 30 cases, 11 patients were in the age group of 40 an5 years. Fifteen out of 30 cases were premenopausal. From 30 cases, 14 patients had tumor size bigger than $5 \mathrm{~cm}$. Sixteen cases had stage III tumor. Most of the cases were invasive ductal carcinoma mammae as their histological features. Two cases had metastized to pleura.

Conclusions: The incidence rate of triple negative breast cancer in Dr. Hasan Sadikin General Hospital is $11.9 \%$ with these common characteristics: range of age are between 40 to 45 years, have a premenopausal, had $>5 \mathrm{~cm}$ tumor , stage III tumor and has histological feature IDC, and only 2 patients were metastized to pleura. [AMJ.2015;2(3):391-94]
\end{abstract}

Keywords: Breast cancer, characteristics, triple negative breast cancer.

\section{Introduction}

Breast cancer is the most frequent type of cancer among women. According to the American Cancer Society, about 207,090 and 230,000 new cases of invasive breast cancer are predicted to occur in American women during 2010 and 2011, respectively. In Indonesia, breast cancer is also the most frequent type of cancer that has been diagnosed among women, with incidence rate 26/100,000 people..$^{1-3}$

Breast cancer can be classified into histological classification, which is taken from the World Health Organization, and molecular classification, that can be obtained from an analysis of gene expression. ${ }^{4,5}$ Molecular classification needs to be determined because the histological classification will not capture all clinical courses of the disease. In patients with identical tumor histologically, different clinical courses can be found on them. That is because they have molecular differences among cancers. Detailed molecular analysis can obtain the information that will improve prognostic prediction. ${ }^{6}$

One of the molecular classification subtype that has been studied recently is triple negative breast cancer. This subtype of breast cancer has a negative expression of estrogen receptors, progesterone receptors, and HER-

Correspondence: Nadytia Kusumadjayanti, Faculty of Medicine, Universitas Padjadjaran, Jalan Raya BandungSumedang Km.21, Jatinangor, Sumedang, Indonesia, Phone: +6281572242601 Email: nadytiaks@yahoo.com 
2 (human epidermal growth factor 2). This subgroup does not respond to hormonal therapy or other targeted therapy. It makes the disease tend to have poor prognosis. ${ }^{7}$

This study aimed to find the incidence cases and the characteristics of triple negative breast cancer in Dr. Hasan Sadikin General
Hospital, Bandung.

\section{Methods}

This study was conducted with the crosssectional descriptive method. Data were taken from the medical records of triple negative

Table 1 Characteristics of triple negative breast cancer $(\mathrm{N}=30)$

\begin{tabular}{|c|c|}
\hline Characteristics & Number of cases \\
\hline \multicolumn{2}{|c|}{ Age at presentation (years) (range 31076) } \\
\hline$<40$ & 10 \\
\hline 40055 & 11 \\
\hline$>55$ & 9 \\
\hline \multicolumn{2}{|l|}{ Menopausal status } \\
\hline Premenopausal & 15 \\
\hline Menopausal & 6 \\
\hline Postmenopausal & 9 \\
\hline \multicolumn{2}{|l|}{ Tumor size $(\mathrm{cm})$ (range1国15) } \\
\hline$<2$ & 3 \\
\hline 2 20 & 12 \\
\hline$>5$ & 14 \\
\hline Not listed & 1 \\
\hline \multicolumn{2}{|l|}{ Stage at presentation } \\
\hline II & 8 \\
\hline III & 16 \\
\hline IV & 2 \\
\hline Not listed & 4 \\
\hline \multicolumn{2}{|l|}{ Tumor grade } \\
\hline 2 & 10 \\
\hline 3 & 16 \\
\hline Not listed & 4 \\
\hline \multicolumn{2}{|l|}{ Histologic subtype } \\
\hline IDCM & 24 \\
\hline ILCM & 3 \\
\hline Mixed IDCM and ILCM & 1 \\
\hline Metaplastic carcinoma mammae & 1 \\
\hline Secretory carcinoma mammae & 1 \\
\hline \multicolumn{2}{|l|}{ Metastatic status } \\
\hline Yes (pleural effusion) & 2 \\
\hline No & 25 \\
\hline Unknown & 3 \\
\hline
\end{tabular}

Note: IDCM= invasive ductal carcinoma mammae; ILCM= invasive lobular carcinoma mammae 
patients in Dr. Hasan Sadikin General Hospital during January 2010?December 2011. The parameters such as age presentation, menopausal status, tumor size, stage at presentation, pathological features and grades, and metastatic status were evaluated.

Data collection was carried out in the Department of Anatomical Pathology to collect the patients' data where the immune histochemistry was tested. Among 252 cases tested, 30 cases were triple negative. Age at presentation, pathological features and grades, tumor size, stage of tumor, menopause status, and metastatic status were taken from the medical records of the patients.

The collected data were analyzed using the statistical software SPSS version 20 and presented in tables. Data were collected during September? November 2012.

\section{Results}

Data from 1 January 2010?31 December 2011 showed that 252 breast cancer patient were immunohistochemistry tested, and 30 cases (11.9\%) were triple negative breast cancer. The characteristics of 30 cases triple negative breast cancer are shown in Table 1. Ten cases were below the age of 40 , with the youngest age was 31 . Fifteen from 30 cases of triple negative breast cancer were premenopausal. Tumor size of 14 cases was above $5 \mathrm{~cm}$ and most of the cases had stage III tumor.

In this study, triple negative breast cancer cases were mostly in grade $3(16 / 30)$ and invasive ductal carcinoma mammae was the most common subtype (24/30). There were only 2 cases that were already metastized to pleura

\section{Discussion}

The incidence of triple negative breast cancer in Dr. Hasan Sadikin General Hospital stands at $11.9 \%$, within the range of 10 ? $17 \%$ reported in a literature written by Reis-Filho et al. ${ }^{8}$ The distribution of age in this study indicates that most of the cases are in the age group of 40055 years. This result is in line with the data results from British Columbia, Canada. ${ }^{9}$ Besides, it must be noted that the youngest person in the case was 31 years old meaning that this subtype of breast cancer also can affect younger patients. This result is supported by the result of menopausal status distribution showing that $50 \%$ cases are premenopausal This result is similar to the a study in the Carolina Breast Cancer Study. ${ }^{10}$ However, this study result is different from the study result in Singapore, which shows that most of the triple negative breast cancer cases were in postmenopausal group. ${ }^{11}$

Most of the triple negative cases in our population had a tumor size more than $5 \mathrm{~cm}$. This result is different from the data in Canada, where most of these cases had tumor size in between 2 ? $5 \mathrm{~cm} .{ }^{9}$ In this study, it can be concluded that half of the population (53.3\%) had stage III tumor on the day they went to the doctor'. These results were also varied from a previous study by Keegan et al. ${ }^{12}$. It shows that in their population, triple negative breast cancer cases have come to the doctor's when they had stage II.

Histological type and grades in this study confirmed a morphologically aggressive phenotype, with most of cases had stage III tumor, similar to the study carried out in Canada. ${ }^{9,13}$ From these data, it can be concluded that triple negative breast cancer are highly differentiated so that this subtype has a poor prognosis. Pathological features of triple negative breast cancer cases in Dr. Hasan Sadikin General Hospital are predominantly invasive ductal carcinoma mammae. This result confirms the study in Singapore, as well as in Nigeria and Senegal. ${ }^{11,14}$ Furthermore, metaplastic, medullary, and secretory carcinoma subtype are also found in triple negative breast cancer. ${ }^{14,15}$ The study explains about findings in our data, which had one case of metaplastic type and also secretory type of carcinoma.

On metastatic status, from 30 cases, there were two cases that had already metastized and both of them metastized to pleura. Those cases confirm the previous study in Toronto. The study concludes that the triple negative breast cancer tends to metastize to visceral region, especially lungs and brain. ${ }^{16}$ These varied findings aimed to give information about metastatic status within the first year of the study. Till the end of December 2011, there are only two cases metastized. Based on this study, it can be concluded that the incidence of triple breast cancer and the characteristics of patients are in accordance with other previous studies.

Short period of time became the limitation for this study. The period during January 2010? December 2011 was chosen because immunohistochemistry test for breast cancer in Dr. Hasan Sadikin General Hospital started in 2010. Therefore, this study has only a few data, although it has used the total sampling 
method. It is possible that this study does not illustrate the reality in the field. This study has not illustrated the majority race of triple negative breast cancer case because there is not enough information about it in the medical records.

\section{References}

1. American Cancer Society. Breast cancer facts \& figures 2010?2011. Atlanta: American Cancer Society, Inc.; 2011.

2. American Cancer Society. Cancer facts \& figures 2010. Atlanta: American Cancer Society, Inc.; 2010.

3. Kementerian Kesehatan Republik Indonesia. Jika tidak dikendalikan 26 juta orang di dunia menderita kanker. Kementerian Kesehatan Republik Indonesia. 2012. [Cited 2012 April 9]. Available from: http://www.depkes.go.id/ index.php/berita/press-release/1060jika-tidak-dikendalikan-26-juta-orang-didunia-menderita-kanker-.html

4. Tavassoli FA, Devilee P, World Health Organization, International Agency for Study on Cancer. Pathology and Genetics of Tumours of the Breast and Female Genital Organs. Lyon: IARC Press; 2003.

5. Yang XR, Sherman ME, Rimm DL, Lissowska J, Brinton LA, Peplonska B, et al. Differences in risk factors for breast cancer molecular subtypes in a population-based study. Cancer Epidemiol Biomarkers Prev. 2007;6(3):439? 43.

6. Pusztai L, Mazouni C, Anderson K, Wu Y, Symmans WF. Molecular classification of breast cancer: limitation and potential. Oncologist. 2006;11(8):868?77

7. Foulkes WD, Smith IE, Reis-Filho JS. Triplenegative breast cancer. N Engl J Med. 2010;363(20):1938?48
8. Reis-Filho JS, Tutt AN. Triple negative tumours: a critical review. Histopatology. 2008;52(1):108?18

9. Voduc KD, Cheang MCU, Tyldesley S, Gelmon K, Nielsen TO, Kennecke $\mathrm{H}$. Breast cancer subtypes and the risk of local and regional relapse. J Clin Oncol. 2010;28(10):1684国91

10. Anders C, Carey LA. Understanding and treating triple-negative breast cancer. Oncology (Williston Park). 2008;22(11):1233国9.

11. Thike AA, Cheok PY, Jara-Lazaro AR, Tan B, Tan P, Tan PH. Triple-negative breast cancer: clinicopathological characteristics and relationship with basal-like breast cancer. Mod Pathol. 2010;23(1):123国33.

12. Keegan T, DeRouen M, Press D, Kurian A, Clarke C. Occurrence of breast cancer subtypes in adolescent and young adult women. Breast Cancer Res. 2012; 14(2):R55.

13. Dent R, Trudeau M, Pritchard KI, Hanna WM, Kahn HK, Sawka CA, et al. Triplenegative breast cancer: clinical features and patterns of recurrence. Clin Cancer Res. 2007;13(15):4429?34.

14. Huo D, Ikpatt F, Khramtsov A, Dangou J-M, Nanda R, Dignam J, et al. Population differences in breast cancer: survey in indigenous African women reveals overrepresentation of triple-negative breast

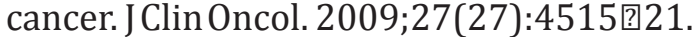

15. Hudis CA, Gianni L. Triple-negative breast cancer: an unmet medical need. Oncologist. 2011;16(suppl 1):1011.

16. Dent R, Hanna WM, Trudeau M, Rawlinson E, Sun P, Narod SA. Pattern of metastatic spread in triple-negative breast cancer. Breast Cancer Res Treat. 2009;115(2):423国8. 